\title{
ОСОБЛИВОСТІ ВМІСТУ ДЕЯКИХ МЕТАБОЛІЧНИХ ПОКАЗНИКІВ ТА ТУМОРНЕКРОТИЧНОГО ФАКТОРА У ХВОРИХ НА КОМОРБІДНУ ПАТОЛОГІЮ
}

\author{
๑Ю. Г. Бурмак, Є. Є. Петров, С. І. Треумова \\ Вищий державний навчальний заклад України «Українська медична стоматологічна академія», \\ м. Полтава
}

РЕЗЮмЕ. Відомо, що в регуляції трофічних та репаративних процесів тканин значну роль відіграють метаболіти арахідонової кислоти та ліпоперекисні похідні, що підкреслює їх важливу роль у рецидивуванні та/ або хронізації запального процесу. Окрім того, не виключається їх значно більший вплив на перебіг захворювань в умовах коморбідності.

Мета дослідження - вивчення вмісту ліпооксигеназних метаболітів арахідонової кислоти (лейкотрієни (LT) C4 і B4; радіоімунний метод), проміжної та кінцевої ліпоперекисних сполук (дієнові кон'югати (DC) та малоновий діальдегід (MDA); спектрофотометричний метод), а також сироваткового туморнекротичного фактора а (TNFa; імуноферментний метод) у ході лікування 40 хворих (вік 37 - 49 років, 25 чоловіків та 15 жінок) на пептичну виразку (ПВ), у 23 з яких вона була коморбідною із хронічним бронхітом; референтною нормою були показники 20 практично здорових осіб (групи не відрізнялись за віком і статтю).

Виявилось, що у коморбідних хворих після лікування рівень LTB4, порівняно з хворими на ПB $((108,5 \pm 20,6)$ пг/ мл), був підвищеним у 1,3 раза (у здорових - $((53,2 \pm 11,4)$ пг/мл; $p<0,001)$ і більш ніж в 1,4 раза перевищував рівень LTC4 (у хворих на ПВ - $(98,7 \pm 18,9)$ пг/мл; референтна норма - $(39,7 \pm 10,4)$ пг/мл; р<0,001). 3'ясовано, що підвищення вмісту ліпооксигеназних метаболітів АК у хворих на коморбідну патологію супроводжувалось також суттєвим підвищенням рівня проміжних і кінцевих ліпоперекисних сполук, при цьому рівень DC у хворих з коморбідною патологією перевищував такий у хворих на ПВ майже на третину $((6,81 \pm 0,33)$ мкмоль/л, $p<0,001)$, a вміст MDA - більш ніж на чверть $((9,53 \pm 0,41)$ мкмоль/л, $p<0,001)$. Вказані зміни метаболічних показників у коморбідних хворих після лікування супроводжував більш ніж удвічі підвищений вміст сироваткового TNFa $((51,0 \pm 2,8)$ пг/мл; у здорових - $(24,5 \pm 3,2)$ пг/мл; p<0,001), що було також у 1,34 раза вище, ніж у хворих на ПВ після лікування. Виявлені особливості вмісту ліпооксигеназних метаболітів арахідонової кислоти, проміжного та кінцевого ліпоперекисних сполук та прозапального TNFa після лікування у хворих на коморбідну патологію свідчать про збереження у них високої прозапальної активності крові, що передбачає розробку заходів з оптимізації лікування та профілактики означеної патології у вказаної категорії хворих.

КлючовІ СЛОВА: пептична виразка; хронічний бронхіт; туморнекротичний фактор а; арахідонова кислота.

\section{ОСОБЕННОСТИ СОДЕРЖАНИЯ НЕКОТОРЫХ МЕТАБОЛИЧЕСКИХ ПОКАЗАТЕЛЕЙ И ТУМОРНЕКРОТИЧЕСКОГО ФАКТОРА У БОЛЬНЫХ КОМОРБИДНОЙ ПАТОЛОГИЕЙ}

\section{๑Ю. Г. Бурмак, Е. Е. Петров, С. И. Треумова}

Высшее государственное учебное заведение Украины «Украинская медицинская стоматологическая академия», г. Полтава

РЕЗЮМЕ. Известно, что в регуляции трофических и репаративных процессов тканей значительную роль играют метаболиты арахидоновой кислоты и липоперекисные производные, что подчеркивает их важную роль в рецидивировании и / или хронизации воспалительного процесса и, кроме того, не исключается их значительно большее влияние на течение заболеваний в условиях коморбидности.

Целью исследования стало изучение содержания липооксигеназных метаболитов арахидоновой кислоты (лейкотриены (LT) C4 и B4; радиоимунний метод), промежуточного и конечного липоперекисных соединений (диеновые конъюгаты (DC) и малоновый диальдегид (MDA); спектрофотометрический метод), а также сывороточного туморнекротического фактора а (TNFa; иммуноферментный метод) в ходе лечения 40 больных (возраст 37 - 49 лет, 25 мужчин и 15 женщин) язвенной болезнью (ЯБ), у 23 из которых она была коморбидной с хроническим бронхитом; референтной нормой были показатели 20 практически здоровых лиц (группы не различались по возрасту и полу).

Оказалось, что у коморбидных больных после лечения уровень LTB4, по сравнению с больными ПB $((108,5 \pm 20,6)$ пг/мл) был повышенным в 1,3 раза (у здоровых - $(53,2 \pm 11,4)$ пг/мл p<0,001) и более чем в 1,4 раза - уровень LTC4 (у больных ЯБ - $(98,7 \pm 18,9)$ пг/мл референтная норма - $(39,7 \pm 10,4)$ пг/мл, р<0,001). Выяснено, что повышение содержания липооксигеназных метаболитов АК у больных с коморбидной патологией сопровождалось также существенным повышением уровня промежуточных и конечных липоперекисных соединений, при этом уровень DC у больных коморбидной патологией превышал таковой у больных ЯБ почти на треть $((6,81 \pm 0,33)$ мкмоль/л, p<0,001), а содержание MDA - более чем на четверть $((9,53 \pm 0,41)$ мкмоль/л, $p<0,001)$. 
Огляди літератури, оригінальні дослідження, погляд на проблему, короткі повідомлення

Указанные изменения метаболических показателей у коморбидных больных после лечения сопровождало более чем вдвое повышенное содержание сывороточного TNFa $((51,0 \pm 2,8)$ пг/мл, у здоровых - $(24,5 \pm 3,2)$ пг/ мл, p<0,001), что было также в 1,34 раза выше, по сравнению с больными Пв после лечения. Найденные особенности содержания липооксигеназных метаболитов арахидоновой кислоты, промежуточного и конечного липоперекисних соединений и провоспалительных TNFa после лечения у больных коморбидной патологии свидетельствуют о сохранении у них высокой провоспалительной активности крови, предусматривает разработку мероприятий по оптимизации лечения обозначенной патологии у указанной категории больных.

КЛЮЧЕВЫЕ СЛОВА: пептическая язва; хронический бронхит; туморнекротический фактор а; арахидоновая кислота.

\title{
CERTAIN CONTENT FEATURES AND TUMORNECROTIC METABOLIC FACTORS IN PATIENTS WITH COMORBID DISEASES
}

\author{
@Yu. H. Burmak, Ye. Ye. Petrov, S. I. Treumova \\ Ukrainian Academy of Medical Dental Poltava
}

SUMMARY. It is known that the regulation of trophic and reparative processes of tissues play a significant role metabolites of arachidonic acid and lipoperoxide derivatives, which emphasizes their role in recurrence and / or chronization inflammation and, moreover, does not exclude them much greater influence on the course of diseases in comorbidity .

The aim was to study the contents of lipoxygenase metabolites of arachidonic acid (leukotrienes (LT) B4 and C4; radio immune method), and finished lipid peroxyl compounds (diene conjugates (DC) and malonic dyaldehyde (MDA); spectrophotometric method) and serum tumornecrotic factor a (TNFa; immune enzyme method) during the treatment of 40 patients (age 37 - 49 years, 25 men and 15 women), peptic ulcer disease (UD), in 23 of which it was comorbid with chronic bronchitis; Reference rate figures were 20 healthy individuals (groups did not differ by age and gender).

It was found that comorbid patients after treatment LTV4 level compared with patients Visitor Messages $(108.5 \pm 20.6 \mathrm{pg} / \mathrm{ml})$ was increased 1.3 times (healthy $-53.2 \pm 11.4 \mathrm{pg} / \mathrm{ml} ; \mathrm{p}<0.001)$ and more than 1.4 times - LTS4 level (in patients Visitor Messages - $98.7 \pm 18.9 \mathrm{pg} / \mathrm{mL}$; reference rate $-39.7 \pm 10.4 \mathrm{pg} / \mathrm{ml}, \mathrm{p}<0.001$ ). It is found, something increased content lipoxygenaze AK metabolites in patients with comorbid diseases was also accompanied by significant increase in the level of intermediate and final lipoperoxide compounds, while the UC level in patients with comorbid disorders higher than that of patients at the Preparatory almost around one third $(6.81 \pm 0.33 \mathrm{mmol} / \mathrm{l}, \mathrm{p}<0.001)$, and the content of MDA - more than a quarter $(9.53 \pm 0.41 \mathrm{mmol} / \mathrm{l}, \mathrm{p}<0.001)$. These metabolic changes in comorbid patients after treatment was accompanied by more than half, increased serum TNFa $(51.0 \pm 2.8 \mathrm{pg} / \mathrm{ml}$ in healthy $-24.5 \pm 3.2 \mathrm{pg} / \mathrm{ml}$, $\mathrm{p}<0.001)$ which was also 1.34 times higher compared with patients at the Preparatory after treatment. Found features content lipoxygenaze metabolites of arachidonic acid, and finished lipoperoxide compounds and pro-inflammatory TNFa after treatment in patients with comorbid diseases show preserving their high blood inflammatory activity that involves the development of measures to optimize the treatment and prophylaxis of the designated disease in this category of patients.

KEY WORDS: peptic ulcer; chronic bronchitis; tumornecrotic factor a; arachidonic acid. 